\title{
Sexual reproduction of the invasive green alga Caulerpa racemosa var. occidentalis in the Mediterranean Sea
}

\author{
Panayotis PANAYOTIDIS ${ }^{a}$, Ante ŽULJEVIĆc $*$ \\ ${ }^{a}$ National Centre for Marine Research, Agios Kosmas, 16604 Athens, Greece \\ ${ }^{\mathrm{b}}$ Institute of Oceanography and Fisheries, šet. I. Meštrovića 63, 21000 Split, Croatia
}

Received 19 June 2000; revised 14 December 2000; accepted 19 December 2000

\begin{abstract}
Since the beginning of the 1990s, a pan-tropical species Caulerpa racemosa var. occidentalis has been recorded on the numerous new locations throughout the Mediterranean, specifically on its northwestern part where until then it had never been observed. Such extensive spreading is probably supported by successful sexual reproduction. Field observations of fertile plants and synchronous gamete release of $C$. racemosa var. occidentalis were carried out in Saronikos Gulf (Greece, Aegean Sea) at the beginning of July 1999. The fertile plants were detected due to reticulate depigmented protoplasmic masses and cylindrical papillae. The alga is monoecious. The both sex gametes were released synchronously from all the fertile plants approximately $14 \mathrm{~min}$ before sunrise and formed a green gamete cloud. Although both sex gametes were present, low gamete compatibility was noted during the laboratory examination.

(C) 2001 Ifremer/CNRS/IRD/Éditions scientifiques et médicales Elsevier SAS
\end{abstract}

Résumé - Reproduction sexuée de l'algue envahissante Caulerpa racemosa var. occidentalis en Méditerranée. Depuis le début des années 1990, l'algue tropicale Caulerpa racemosa var. occidentalis a été observée dans de nombreux nouveaux sites de Méditerranée nord-occidentale où elle était jusqu'alors inconnue. Une dispersion d'une telle ampleur est probablement due à une reproduction sexuée particulièrement efficace. Des observations de plants fertiles de C. racemosa var. occidentalis et des lâchers simultanés de gamètes ont été menés dans le golfe de Saronikos (mer Egée) au début du mois de juillet 1999. Les thalles fertiles se distinquent par leur protoplasme dépigmenté et la présence de papilles cylindriques. L'algue est monoïque. Les gamètes mâles et femelles sont expulsés de façon synchrone environ 14 min avant le lever du soleil et forment un nuage vert. En dépit de la présence des deux sexes, une faible compatibilité entre les deux types de gamètes a été observée au laboratoire. () 2001 Ifremer/CNRS/IRD/Éditions scientifiques et médicales Elsevier SAS

Caulerpa racemosa var. occidentalis / Mediterranean Sea / sexual reproduction

Caulerpa racemosa var. occidentalis / Méditerranée / reproduction sexuée

*Correspondence and reprints: fax: +38521358650 .

E-mail addresses: zuljevic@izor.hr (A. ŽULJEVIĆ), ppanag@erato.fl.ncmr.gr (P. PANAYOTIDIS). 


\section{INTRODUCTION}

The presence of Caulerpa racemosa var. occidentalis (J. Agardh) Børgesen in the Mediterranean Sea has been reported for the first time in Tunisia by Hamel (1926). From that time till the beginning of the 1990s, the alga has been sporadically noted only throughout the eastern basin of the Mediterranean (Boudouresque et al., 1990; Djellouli et al., 1998).

Since the beginning of the 1990s, within a few years, the distribution of C. racemosa var. occidentalis has amazingly extended throughout the eastern and western part of the Mediterranean, usually forming a dense and large population with invasive behaviour: Egypt (Aleem, 1992), Cyprus (Argyrou et al., 1999; Hadjichristophorou, et al., 1997), Malta (Stevens, 1999), Turkey (Cirik and Öztürk, 1991), Greece (Chryssovergis and Panayotidis, 1998; Panayotidis and Montesanto, 1994, 1998), Italy (Alongi et al., 1993; Bussotti et al., 1996; Piazzi et al., 1994, 1997), France (Verlaque et al., 2000) and Balearic Islands (Ballesteros et al., 1999). Such a widespread and rapid spreading is probably supported by successful sexual reproduction. Therefore the basic aim of this study was to prove sexual reproduction by field and laboratory observations.

\section{MATERIAL AND METHODS}

Field observations were made by snorkel in a shallow bay (figure 1) in Saronikos Gulf (Greece, Aegean Sea), between 1st and 7 July 1999. The rocky substratum between 0.5 and $1.5 \mathrm{~m}$ deep was almost completely covered by $C$. racemosa var. occidentalis. The algae was surveyed in the afternoon for detecting, collecting and marking fertile plants, and during the next early morning, before the sunrise for the observation of gamete release. The sea water temperature was $26^{\circ} \mathrm{C}$.

With the aim to observe gametes, the fertile thalli were collected in the afternoon before gamete liberation, and kept in an aquarium at the ambient temperature and seawater without artificial aeration.

\section{RESULTS}

Fertile plants of Caulerpa racemosa var. occidentalis were easily detected due to reticulate depigmented protoplasmic masses contrary to homogeneously coloured non-fertile plants (figure 2). Also, the greatest part of the rhizome became white as a result of the migration of cytoplasm into fronds. Approximately $12 \mathrm{~h}$ before ga-
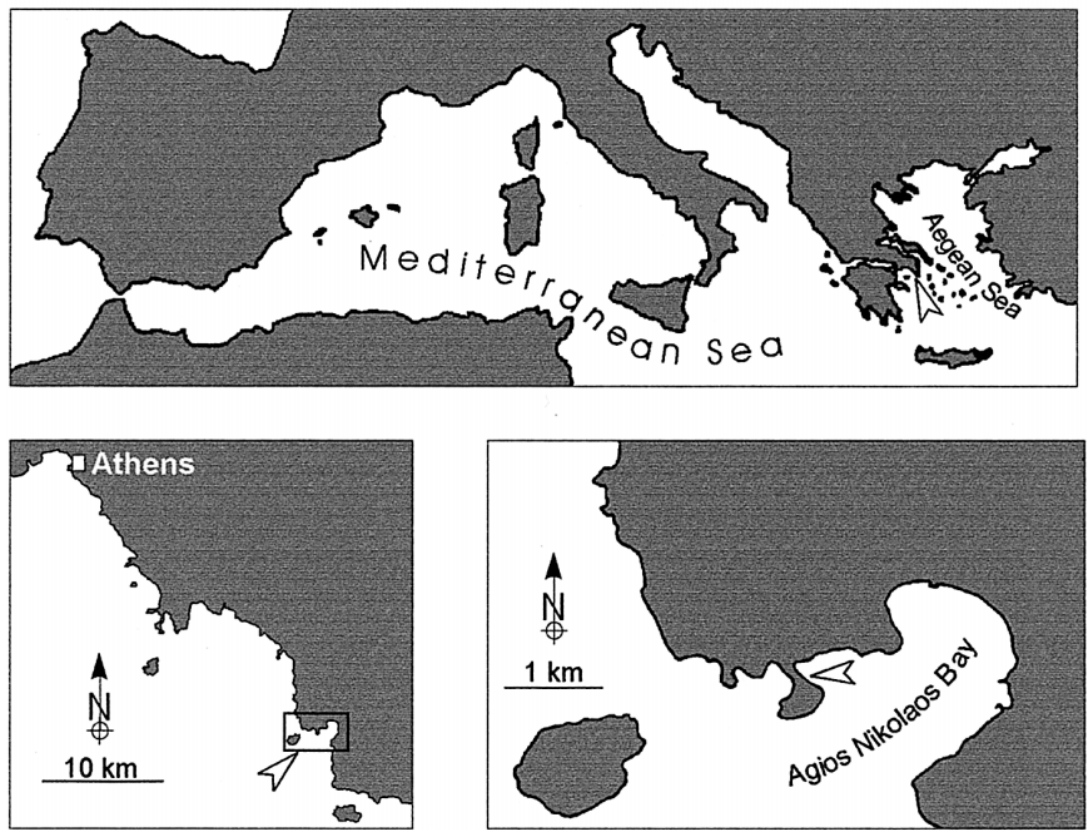

Figure 1. Maps showing the position of the Aegean Sea and the study site (37 $\left.43^{\prime} 30^{\prime} \mathrm{N}, 23^{\circ} 54^{\prime} 50^{\prime} \mathrm{E}\right)$ 

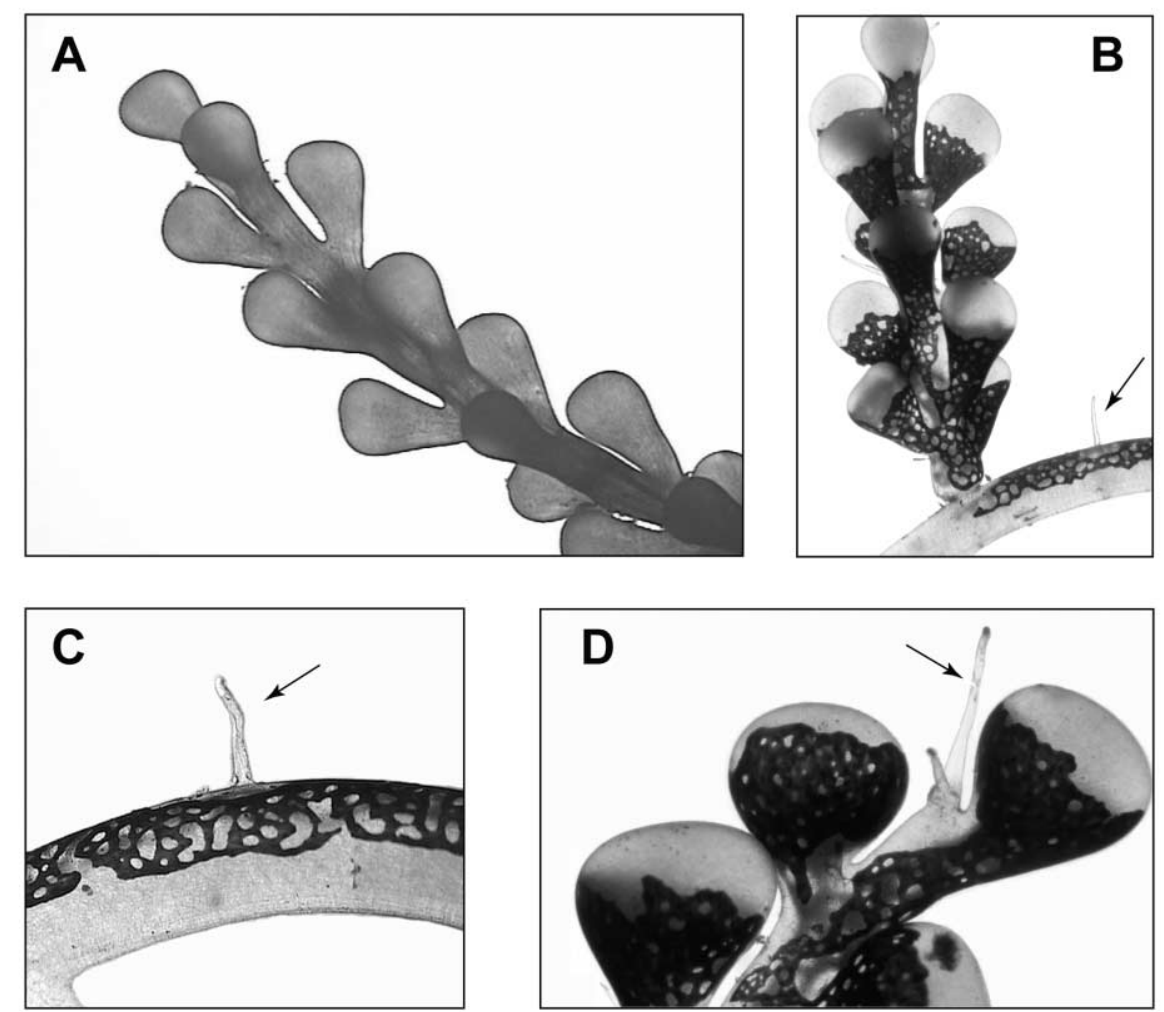

Figure 2. Visible changes of the C. racemosa var. occidentalis thalli during gametogenesis. Uniformly coloured nonfertile thalli (A); reticulate depigmented thalli of fertile algae (B) one day before spawning; detail of a fertile rhizome (C) and frond (D) with papillae (arrows).

mete release, the protoplasmic network became mosaically bicolored in light green and brownish orange.

The changes in protoplasmic consistence were followed by the formation of numerous, slightly white cylindrical papillae, which appeared as outgrowths on the frond axis, branchlets and rhizomes (figure 2).

Liberated gametes formed a large green cloud 1-1.5 m around the mother plant. It usually dispersed within 5-10 min. During liberation, all protoplasmic material streamed out and only white, ghost thalli persisted (holocarpy). All of the fertile plants released their gametes synchronously approximately $14 \mathrm{~min}$ before sunrise: the first gametes cloud appeared $17 \mathrm{~min}$ and the last 12 min before sunrise.

Maintaining the fertile plants in dark in the laboratory, we could postpone the liberation for about $2 \mathrm{~h}$ in comparison to the gamete release in natural conditions. Liberation started a few minutes after illumination.
Microscope observation of the gamete samples showed two types of biflagellate gametes in the same plant: one (female) slightly larger contained an orange stigma, while the other was smaller and without stigma (male). The presence of both sex gametes in the same plant was expected on the basis of bicolored protoplasmic network caused by the sexual segregation of the gametes throughout the thallus and reddish stigma in female gametes (Enomoto and Ohba, 1987; Goldstein and Morall, 1970).

In spite of both sex gametes presence, we observed just a low percentage $(<5 \%)$ of apparent gamete conjugations to form a planozygotes. Because of such a low percentage, the apparent conjugation could be an artefact due to incomplete cleavage of gametes during gametogenesis, which at the moment of observation looked like planozygotes. Further cultivation of the gametes and planozygotes were not done. 


\section{DISCUSSION}

Our results confirm previous reports of Caulerpa racemosa sexual reproduction, which showed that the species was monoecious, producing both sex gametes on the same plants: Caribbean specimens of $C$. racemosa (Forsskål) J. Agardh (Clifton, 1997; Clifton and Clifton, 1999; Goldstein and Morall, 1970), C. racemosa var. laetevirens (Montagne) Weber van Bosse and C. racemosa var. peltata (Lamouroux) Eubank from Japan (Enomoto and Ohba, 1987; Ohba and Enomoto, 1987; Ohba et al., 1992), C. racemosa var. uvifera (C. Agardh) J. Agardh from South India (Iyengar, 1933, 1940).

The apparent low gamete compatibility observed in the studied Mediterranean strain of C. racemosa var. occidentalis could be caused by the inadequacy of the laboratory conditions (ambient temperature, lack of aeration) or by stress due to manipulation of the fertile plants.

Our results also confirm the observations on sexual reproduction of Caribbean C. racemosa (Clifton, 1997; Clifton and Clifton, 1999) regarding the time of the gametes release. Nevertheless, for the Caribbean plants this occurred $32 \mathrm{~min}$ after sunrise in distinction from 14 min before sunrise for the Mediterranean species. This difference is probably due to the shorter period of dawn in the tropical regions.

At the beginning of the 21st century, it seems that the introduced Caulerpa species constitutes a serious threat for the Mediterranean marine biological, ecological and landscape diversity (UNEP, 1999). In less than two decades $C$. taxifolia (Vahl) C. Agardh has covered a large area of the Western Mediterranean Sea, although reproducing only by fragmentation (Meinesz and Hesse, 1991; Meinesz et al., 1998). Caulerpa racemosa var. occidentalis supported by sexual reproduction, together with its remarkable capability of adjustment to the ecological factors such as temperature, substratum and depth (light) (Verlaque et al., 2000), will probably perform a much faster invasion dynamic throughout the Mediterranean Sea.

\section{REFERENCES}

Aleem, A.A., 1992. Caulerpa racemosa (Chlorophyta) on the Mediterranean coast of Egypt. Phycologia 31, 205-206.

Alongi, G., Cormaci,, M., Furnari, G., Giaccone, G., 1993. Prima segnalazione di Caulerpa racemosa (Chlorophyceae, Caulerpales) per le coste italiane, Bollettino delle Sedute Accademia Gioenia Scienze Naturali. Catania 342, 49-53.

Argyrou, M., Demetropoulos, A., Hadjichristophorou, M., 1999. Expansion of the macroalga Caulerpa racemosa and changes in softbottom macrofaunal assemblages in Moni Bay, Cyprus. Oceanol. Acta 22, 517-528.

Ballesteros, E., Grau, A.M., Riera, F., 1999. Caulerpa racemosa (Forsskål) J. Agardh (Caulerpales, Chlorophyta) a Mallorca. Boll. Soc. Hist. Nat. Balears 42, 63-68.

Boudouresque, C.F., Ballesteros, E., Ben Maiz, N., Boisset, F., Bouladier, E., Cinelli, F., Cirik, S., Cormaci, M., Jeudy de Grissac, A., Laborel, J., Lanfranco, E., Mayhoub, H., Meinesz, A., Panayotidis, P., Semroud, R., Sinnassamy, J.M., Špan, A., Vuignier, G., 1990. Livre rouge « Gérard Vuignier »des végétaux, peuplements et paysages marins menacés de Méditerranée, MAP Technical Reports Series No. 43. UNEP, Athens.

Bussotti, S., Conti, M., Guidetti, P., Martini, F., Matricardi, G., 1996. First record of Caulerpa racemosa (Forssk.) J. Agardh along the coast of Genoa (Northwestern Mediterranean). Doriana 6, 1-5.

Chryssovergis, F., Panayotidis, P., 1998. Étude du phytobenthos des côtes sud-est d'Attique, en vue de l'installation du réseau d'assainissement des eaux usées, de la banlieue est d'Athènes (résultats préliminaires). Rapp. Comm. Int. Mer Médit. 35, 530-531.

Cirik, S., Öztürk, B., 1991. Notes sur la présence d'une forme rare du Caulerpa racemosa, en Méditerranée orientale. Flora Mediterranea $1,217-219$.

Clifton, K.E., 1997. Mass spawning by green algae on coral reefs Science 275, 1116-1118.

Clifton, K.E., Clifton, L.M., 1999. The phenology of sexual reproduction by green algae (Bryopsidales) on Caribbean coral reefs. J. Phycol. 35, 24-34.

Djellouli, A., Langar, H., El Abed, A., 1998. Caulerpa racemosa (Forsskål) J. Agardh: biogéographie et écologie. In: Boudouresque, C.F., Gravez, V., Meinesz, A., Palluy, F. (Eds.), Third international workshop on Caulerpa taxifolia. GIS Posidonie publications, Marseille, pp. 233-238.

Enomoto, S., Ohba, H., 1987. Culture studies on Caulerpa (Caulerpales, Chlorophyceae) I. Reproduction and development of $C$. racemosa var laetevirens. Jap. J. Phycol. 35, 167-177.

Goldstein, M., Morrall, S., 1970. Gametogenesis and fertilization in Caulerpa. Ann. NY Acad. Sci. 175, 660-672.

Hadjichristophorou, M., Argyrou, M., Demetropoulos, A., Bianchi, T.S., 1997. A species list of the sublittoral soft-bottom macrobenthos of Cyprus. Acta Adriat. 38, 3-32.

Hamel, G., 1926. Quelques algues rares ou nouvelles pour la flore méditerranéenne. Bull. Mus. Nat. Sci. Nat. Paris 32, 420.

Iyengar, M.O.P., 1933. On the formation of gametes in a Caulerpa. J. Indian Bot. Soc. 12, 325.

Iyengar, M.O.P., 1940. On the formation of gametes in a Caulerpa. J. Indian Bot. Soc. 18, 191-194.

Meinesz, A., Hesse, B., 1991. Introduction et invasion de l'algue tropicale Caulerpa taxifolia en Méditerranée nord-occidentale. Oceanol. Acta 14, 415-426. 
Meinesz, A., Cottalorda, J.M., Chiavérini, D., Cassar, N., Vaugelas, J. de, Antolić, B., Ballesteros, E., Belsher, T., Ceccherelli, G., Cinelli, F., Orestano, C., Grau, A.M, Jaklin, A., Pou, S., Sandulli, R., Špan, A., Zavodnik, N., Žuljević, A., 1998. Bilan et analyse de la situation de l'expansion de Caulerpa taxifolia en Méditerranée à la fin de 1997. In: Meinesz, A., Cottalorda, J.M., Chiavérini, D., Cassar, N., de Vaugelas, J. (Eds.), Suivi de l'invasion de l'algue tropicale Caulerpa taxifolia en Méditerranée: situation au 31 décembre 1997. LEML Université de Nice-Sophia Antipolis publications, Nice, pp. 7-24.

Ohba, H., Enomoto, S., 1987. Culture studies on Caulerpa (Caulerpales, Chlorophyceae) II. Morphological variation of C. racemosa var. laetevirens under various culture conditions. Jap. J. Phycol. 35, $178-188$.

Ohba, H., Nashima, H., Enomoto, S., 1992. Culture studies on Caulerpa (Caulerpales, Chlorophyceae) III. Reproduction, development and morphological variation of laboratory-cultured C. racemosa var. peltata. Bot. Mag. 105, 589-600.

Panayotidis, P., Montesanto, B., 1994. Caulerpa racemosa (Chlorophyta) on the Greek coasts. Cryptogamie, Algol. 15, 159-161.
Panayotidis, P., Montesanto, B., 1998. Recent expansion of Caulerpa racemosa (Chlorophyta) in the Mediterranean. In: Boudouresque, C.F., Gravez, V., Meinesz, A., Palluy, F. (Eds.), Third International Workshop on Caulerpa taxifolia. GIS Posidonie publications, Marseille, pp. 239-241.

Piazzi, L., Balestri, E., Cinelli, F., 1994. Presence of Caulerpa racemosa in the North-Western Mediterranean. Cryptogamie Algol. $15,183-189$.

Piazzi, L., Balestri, E., Magri, M., Cinelli, F., 1997. Expansion de l'algue tropicale Caulerpa racemosa (Forsskål) J. Agardh (Bryopsidophyceae, Chlorophyta) le long de la côte Toscane (Italie). Cryptogamie Algol. 18, 343-350.

Stevens, D.T., 1999. Country report - Malta. Proceedings of the workshop on invasive Caulerpa species in the Mediterranean, MAP Technical Reports Series No. 125. UNEP, Athens, pp. 279-281.

UNEP, 1999. Proceedings of the workshop on invasive Caulerpa species in the Mediterranean, Heraklion, Crete, Greece, MTS No. 125. UNEP, Athens.

Verlaque, M., Boudouresque, C.F., Meinesz, A., Gravez, V., 2000. The Caulerpa racemosa complex (Caulerpales, Ulvophyceae) in the Mediterranean Sea. Bot. Mar. 43, 49-68. 